\title{
Impact of Career Progression on Employee Productivity in Banking Industry
}

\author{
Dr. Swapna.H.R, Associate Professor, The Oxford College of Business Management, \\ swapna.hulimavu@gmail.com \\ Dr. Kalavathy.K.S, Associate Professor, The Oxford College of Business Management, \\ Ks.kalavathy2003@gmail.com
}

\section{Desai Krishna Gayathri, Assistant Professor, T. John Institute of Management \& Science, Gayathridesai.ashok@gmail.com}

\begin{abstract}
Career development refers to the path where one is proceeding in his work life. As the career of an employee spans over his/her entire lifetime, it has to be designed and planned appropriately. This planning depends on various factors like: Need, Abilities, Basic values, Career motives, Destiny and the available opportunities.A recent study by the Institute of Manpower Studies has found that technology has had an influence on career progression within financial institutions resulting in an expansion of the 'professional' tier.The study is based on a survey using a structured questionnaire and data collected from 335 bank employees. Statistical methods like factor analysis, ANOVA and Regression were used to analyze the data.
\end{abstract}

Keywords: Career Progression, Employee Productivity, Public Sector and Private Sector Banks.

\section{INTRODUCTION}

In this today's more competitive business world, it is not only important for the organizations to earn profit but it has become most important to satisfy competitive employees. Retention of employees is not so easy, until an organization provide them with intrinsic/extrinsic rewards and opportunities for career progression. This can be done through career counseling and goal setting, so that employees can understand their abilities and take correct action plans to fulfill their career goals. One must be aware of his development goals to plan accordingly. Career development planning is important for both the individuals and for the organization because it is not possible to plan for the career without identifying the needs of organization and competencies of employees. So organization "es needs cannot be satisfied without satisfying individual needs (Pathak Neetu, 2008)).Career development refers to the path where one is proceeding in his work life. As the career of an employee spans over his/her entire lifetime, it has to be designed and planned appropriately. This planning depends on various factors like: Need, Abilities, Basic values, Career motives, Destiny and the available opportunities.

So a careful and a meticulous career planning has to be deliberately attempted by an individual to assess his or her own talents, skills, interests, values, opportunities, possibilities and repercussions. This involves distinguishing ones career goals and establishing plans for achieving the set goals.
The role of Human Resource Department in an organization is to identify the stages in an individuals' career and assist them in the development endeavors they face at each phase. Thus it is the responsibility of the organizations in career planning of an individual and plays a pivotal role for the following reasons:

$\approx$ The importance for personal life planning and quality of work life.

$\approx$ Less advancement opportunities due to slow economic growth.

$\approx$ High academic levels and professional desires.

Roe's Theory of Career Choice (1956) proposed by Anne Roe suggests that differences in childhood experiences were mirrored in later options of professions. According to Anne all occupations are classified on the two dimensions viz., Field and Level. The primary focus on profession and the interests of an individual form the basis of Field dimension. And the level dimension is stated in terms of capacity, leadership and expertise in occupation. She concludes that to foresee the accurate general professional category of an individual, a cautious appraisal of a person's childhood and their cognizance of his/her parents' attitudes and child's flair should be greatly considered. 


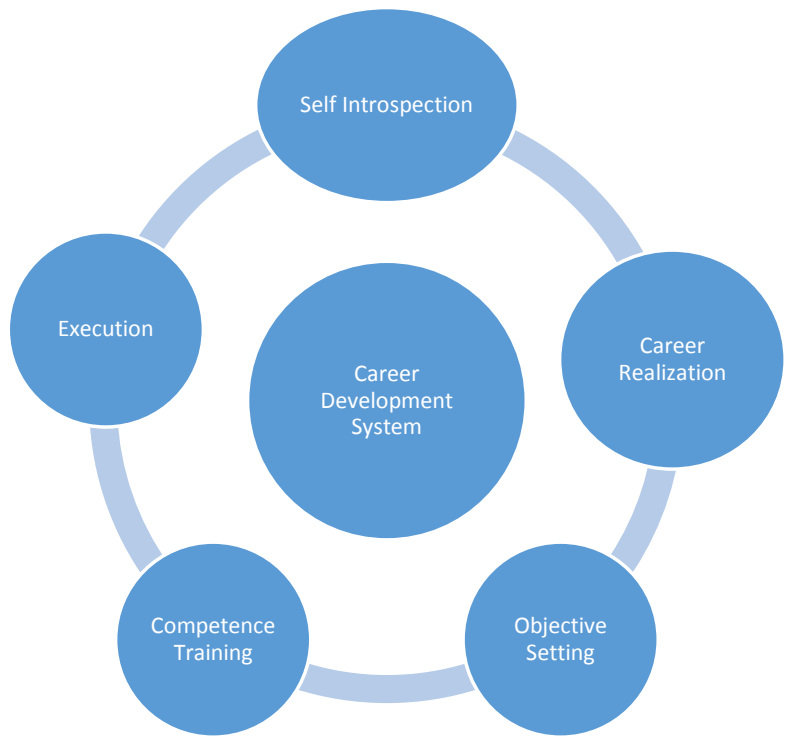

Figure 1: Career Development Plan of an Individual (source: Google images)

Effective and efficient Career Development plans both by the individual and the organization lead to motivation and satisfaction of the jobs over time and later success in career. The positive impact of an initial assignment/job assures the retention and challenges the individual to constantly monitor his/her career planning phases at entry level, Mid-Career, and Retirement levels.

\section{Career Progression in banks}

The term Motivation plays as a buzz word for effective and efficient performance of an employee. The following attributes impact on the satisfaction level of an employee:

- Having Transparency in career path

- A better expressed and communicated career path

- Team dynamics and effective motivating leadership

- Harmony at branches or offices.

- Privileged obligations associated by prestige, wider span of control, etc.

- Responsibilities and tasks with a scope of personal growth

\section{Career Path in Banking Industry}

The career plans in Public sector banks focus on providing more satisfaction to the employees. Career planning is said effective when all the above mentioned elements are considered by chalking out the job sequences of the employee, where each and every employee has to move through in his service journey. However career planning do not always guarantee success or promotion, it only tells the employees where exactly he stands in his career ladder and after some years his expected career path. However in both public and private sector banks the career phases stand same. The difference is that the career path in public sector banks mostly based on seniority; whereas in private sector banks seniority plus employee performance and capability is also considered.

\section{Phases of career path}

Phase I: Exploratory phase or Initiation phase- This phase starts immediately after joining the organization. In very large organizations this stage is like a new born baby. He explores more and starts to adopt for the culture and acquires new knowledge and skills.

Phase II: Stabilization Phase- This is the phase where the employees stabilizes his position. He takes over many tasks and responsibilities and moves towards promotions.

Phase III: Maintenance Phase- This phase of an employee is considered to be vital. This is the phase where most of the employees embark stagnation. In order to have a fast growth they have to be updating themselves. Especially at this stage banks have to develop special strategies to motivate them in achieving individual and organizational goals.

Phase IV: Declining Stage- This stage is just before retirement. During this stage resettlement courses, post retirement programs are conducted by the banks. (Pattanaik, 1990).

Career path is very important, especially during Maintenance and declining stage. Hence banks have to develop strategies to motivate them and make them efficient employees. They can probably be indulged in different task forces, committees, quality circles etc. which would probably satisfy their esteem and social needs. During declining stage mainly public sector banks offer the employees to choose new career or to take voluntary retirement and start their new businesses. Bansal, 1991 has rightly said that if there are no proper career growth in form of promotions then the employees are obvious to feel dissatisfied and frustrated.

Table 1: Eligibility criteria for promotions

\begin{tabular}{|l|l|l|}
\hline Criteria & Public Sector banks & Private Sector Banks \\
\hline Length of service & $\begin{array}{l}\text { Should work minimum of } 10 \text { years in junior management } \\
\text { category }\end{array}$ & $\begin{array}{l}\text { Should work minimum of } 7 \text { years in junior management } \\
\text { category }\end{array}$ \\
\hline Operational Experience & $\begin{array}{l}\text { Should complete I year in any of the following: } \\
\text {-Accountant System administrator } \\
\text {-Field Officer } \\
\text {-Cash Officer }\end{array}$ & Should have got experience in all the divisions \\
\hline Zone of Consideration & $\begin{array}{l}\text { All officers in zone of consideration shall be evaluated on All officers in zone of consideration are called for } \\
\text { prescribed parameters. On the basis of the marks secured }\end{array}$ & \begin{tabular}{l} 
Written exam. On the basis of the marks secured, \\
\hline
\end{tabular} \\
\hline
\end{tabular}




\begin{tabular}{|l|l|l|}
\hline & $\begin{array}{l}\text { by the officers, in performance appraisal the no. of } \\
\text { vacancies earmarked for normal channel from the zone of } \\
\text { selection }\end{array}$ & $\begin{array}{l}\text { officers equal to thrice the no. of vacancies, under the } \\
\text { channel from the zone of selection. }\end{array}$ \\
\hline Interview & $\begin{array}{l}\text { All officers in zone of selection are interviewed for final } \\
\text { selection }\end{array}$ & Same as in public sector banks \\
\hline Performance & Experience and service is considered & Experience + performance of last 2 years is considered \\
\hline SC/ST Officers & They have liberalization in all the above categories & $\begin{array}{l}\text { Not much liberalization is given but maintain the } \\
\text { minimum norms raised by the government. }\end{array}$ \\
\hline
\end{tabular}

(Source: Handbook on staff matters)

The below table depicts the Service eligibility criteria for promotion to top executive grades of public sector banks

Table 2: Service eligibility criteria for promotion to top executive grades:

\begin{tabular}{|l|l|l|}
\hline Promotion from & Promotion to & $\begin{array}{l}\text { Service eligibility } \\
\text { criteria }\end{array}$ \\
\hline Asst. General Manager & Deputy General manager & 3 years \\
\hline Deputy General Manager & General Manager & 3 years \\
\hline General manager & Chief General Manager & 2 years \\
\hline Chief General Manager & Dy. Managing Director & 1 year \\
\hline
\end{tabular}

[Source: Handbook on staff matters]

\section{LITERATURE REVIEW}

The working life of each and every person passes through a journey of evolutionary stages, which can be termed as career stages. Any person or an individual before joining an organization or embarkment of his profession, will be in 'pre-employment stage' and during this particular stage the individual looks for a job which fulfills their needs and aspirations. Then followed by 'socialization stage' where he gains his values and finally, it's 'advancement stage' where the individual tries to enhance and maintain their position and status (Levinson, 1996). According to Brooks and Seers (2001), the career stages are usually based on chronological order of their age; early career stage (20 to 34 years), mid-career stage (35 to 50 years) and late career stage (50-65 years). According to Mowday (1992) the career stage is based on the tenure of the employee i.e. the work experience of the individual.

Levinson et al. (1996), has propound many career development theories and states that the maintenance of organizational commitment will vary according to their differing career stages. An individual in his early career stages tries to explore different jobs which attracts $\mathrm{him} / \mathrm{her}$; but if it fails they would never hesitate to choose another one (Mowday et al, 1992). Therefore age factor is determined as an important variable influencing organizational commitment, especially in early career stage.

Ornstein, Cron and Slocum (1999), squabble that the career stages can be either based on age or organizational tenure or their position. When tenure is considered as the base then the first two years are considered as trial period, and the tenure from two to ten years is termed as establishment period where every individual is anxious with career success and development. After ten years of tenure, it is termed as maintenance period where the employee tries to keep hold of the accomplishments achieved.

Greenhaus, Callanan and Godshalk (2000), in their study classified career progression under five stages which are as follows: (1) Occupational stage, (2) Organizational Entry stage, (3) Early Career stage, (4) Mid-career stage and (5) Late career stage.

During the early career stage, the opportunities and attractive alternatives vary significantly, resulting in difference of organizational commitment. Whereas, employees traveling in mid-stage assume stability of work life and personal life are more important that jumping in search of alternative opportunities. Individuals in the last stage always want to settle down at one place with maximum satisfaction; most of them even don't hesitate to reject their promotions and that is the reason they are more committed to the organisation. Hence the connection between age and organizational dedication in the middle and later career stages is anticipated to be fragile. These prepositions discussed have been confirmed and proved in number of studies (for example, Morrow and McElroy (1997), Cohen (2001), Meyer and Allen (2003), Winter et al (2000), Kumar and Giri (2009).

Camilo Jose (2010), in his article they state that when employee tenure is increasing then generally he is associated to increased side-bets which makes them to stick in the organization more attractively. As the employees get older in the organization they have perceived their year of service as an investment and they do have a psychological feeling that it would be more difficult to adjust other places if there is a shift in the job, hence forth they tend to be more committed than the youngsters. 


\section{RESEARCH METHODOLOGY}

The study is based on a survey using a structured questionnaire and data collected from 335 bank employees. The sampling technique employed for the research study was convenience sampling.Statistical methods like factor analysis, ANOVA and Regression were used to analyze the data.

\section{DATA ANALYSIS AND INTERPRETATION}

Hypothesis designed for the study are as follows: and ANOVA is considered appropriate for this study.

Table 1: Descriptive Statistics of Career Progression System

\begin{tabular}{|c|c|c|c|c|c|c|c|c|}
\hline \multicolumn{9}{|c|}{ Descriptive Statistics } \\
\hline \multicolumn{9}{|c|}{ Career Progression System } \\
\hline & \multirow[t]{2}{*}{$\mathrm{N}$} & \multirow[t]{2}{*}{ Mean } & \multirow[t]{2}{*}{ Std. Deviation } & \multirow[t]{2}{*}{ Std. Error } & \multicolumn{2}{|c|}{$\begin{array}{l}\text { 95\% Confidence. Interval for } \\
\text { Mean }\end{array}$} & \multirow[t]{2}{*}{ Minimum } & \multirow[t]{2}{*}{ Maximum } \\
\hline & & & & & $\begin{array}{l}\text { Lower } \\
\text { Bound }\end{array}$ & $\begin{array}{l}\text { Upper } \\
\text { Bound }\end{array}$ & & \\
\hline $\begin{array}{l}\text { Public Sector } \\
\text { Banks }\end{array}$ & 146 & 3.5900 & .59277 & .04906 & 3.4931 & 3.6870 & 2.14 & 5.00 \\
\hline $\begin{array}{l}\text { Private Sector } \\
\text { Banks }\end{array}$ & 189 & 3.5850 & .59691 & .04342 & 3.4994 & 3.6707 & 2.14 & 4.71 \\
\hline Total & 335 & 3.5872 & .59423 & .03247 & 3.5233 & 3.6511 & 2.14 & 5.00 \\
\hline
\end{tabular}

Table-2: ANOVA of Career Progression System

\begin{tabular}{|c|c|c|c|c|c|c|}
\hline \multicolumn{7}{|c|}{ ANOVA } \\
\hline \multicolumn{7}{|c|}{ Career Progression System } \\
\hline & Sum of Squares & & & lare & $\mathrm{F}$ & Sig. \\
\hline Between Groups & 7.903 & 3 & 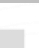 & 2.634 & 7.925 & .000 \\
\hline Within Groups & 110.034 & 331 & & .332 & & \\
\hline Total & 117.937 & 334 & & & & \\
\hline
\end{tabular}

[Source: Compiled from Primary Data]

\section{Statistical Inference:}

$\mathbf{F}(\mathbf{1}, \mathbf{3 3 5})=\mathbf{7 . 9 2 5}>\mathbf{0 . 0 0 0} ; \mathbf{P}<\mathbf{0 . 0 5}$, Hence $\mathbf{H}_{\mathbf{0}}$ is rejected

\section{Theoretical Inference:}

The ANOVA table depicts the F value as 8.463 and the $\mathrm{p}$ value of 0.000 , which is less than the benchmarked $5 \%$ or 0.05 significance level propels us to reject the null hypothesis and accept the alternate hypothesis that both the banking sectors are not equal in terms of the satisfaction score and that there is a significant difference between them.

\section{Regression Analysis}

The dependent variable here is Employee Productivity and the Independent variable is Career Progression System. Hypothesis for this study is as follows:

Null Hypothesis-H0:There is no significant impact between Career Progression System and Employee Productivity.

Alternate Hypothesis-H1: There is a significant impact between career Progression System and Employee Productivity.

Table-3: Model Summary for Hypothesis

\begin{tabular}{|c|c|c|c|c|}
\hline \multicolumn{5}{|c|}{ Model Summary } \\
\hline Model & $\mathbf{R}$ & R Square & Adjusted R Square & Std. Error of the Estimate \\
\hline 1 & $.334^{\mathrm{a}}$ & .112 & .109 & .54070 \\
\hline
\end{tabular}

Table-4: One-way ANOVA

\begin{tabular}{|c|c|c|c|c|c|c|}
\hline \multicolumn{7}{|c|}{ ANOVA $^{a}$} \\
\hline \multicolumn{2}{|c|}{ Model } & Sum of Squares & df & Mean Square & $\mathbf{F}$ & Sig. \\
\hline \multirow[t]{3}{*}{1} & Regression & 12.254 & 1 & 12.254 & 41.915 & $.000^{\mathrm{b}}$ \\
\hline & Residual & 97.354 & 333 & .292 & & \\
\hline & Total & 109.608 & 334 & & & \\
\hline
\end{tabular}


Table-5: Beta Coefficient and T-statistic Results for Hypothesis

\begin{tabular}{|c|c|c|c|c|c|c|c|c|}
\hline \multicolumn{9}{|c|}{ Coefficients } \\
\hline \multirow{2}{*}{\multicolumn{2}{|c|}{ Model }} & \multicolumn{2}{|c|}{ Unstandardized Coefficients } & \multirow{2}{*}{$\begin{array}{c}\begin{array}{c}\text { Standardized } \\
\text { Coefficients }\end{array} \\
\text { Beta }\end{array}$} & \multirow[t]{2}{*}{$\mathbf{t}$} & \multirow[t]{2}{*}{ Sig. } & \multicolumn{2}{|c|}{ 95.0\% Confidence Interval for B } \\
\hline & & B & Std. Error & & & & Lower Bound & Upper Bound \\
\hline \multirow{2}{*}{1} & (Constant) & 2.558 & .181 & & 14.133 & .000 & 2.202 & 2.915 \\
\hline & Career Progression System & .322 & .050 & .334 & 6.474 & .000 & 224 & 420 \\
\hline
\end{tabular}

[Source: Compiled from Primary Data]

\section{RESULTS FOR HYPOTHESIS}

Statistical Inference:

\section{$F(1,335)=41.915>.000^{b} ; P=0.05$, Hence $H_{0}$ is rejected \\ $T_{c v}=6.474>.000 ; P=0.05$, Hence $H_{0}$ is rejected}

\section{Theoretical Inference:}

The regression analysis in Tables3,4 and 5 does not support the null hypothesis and therefore it is not accepted. Alternate hypothesis is retained. The standard beta coefficient is 0.322 for Career Progression System. Fstatistic at degrees of freedom 1 and 335 is 41.915 which is greater than the table value of 0.000 at $p=0.05$. This implies that Employee Productivity is significant determinant of Career Progression System. The positive relation between the dependent and the independent variable is significant at 95 percent confidence level as indicated by $(\mathrm{P}<0.05)$.

\section{MAJOR FINDINGS}

$71 \%$ (239 respondents) of the total respondents always get motivated and engaged by the bank's career planning system. However the mean value on satisfaction level is comparatively high in public sector banks than that of private banks. Out of the total 337 respondents, 175 of them (52\%) expressed that the banks hardly encouraged them for advanced management courses, among which majority of the respondents of $33.2 \%$ (62 respondents) were from Private sector banks have opined that the management is mostly concerned with the profits and not job satisfaction of the employees.

When employeese intention to leave the organization was analyzed then respondents rated career development as most important factor that can also be main cause of satisfaction of employees. The findings of this study support Shelton (2001) that employees ${ }^{\text {ee }}$ intention to leave the organization can be lack of career development, because employees don't want to stay at one job for life time. So majority of employees agreed to leave the organization without climbing the ladder of career development.

\section{SUGGESTIONS}

> The Career Progression path of each employee must be linked to the Performance Appraisal System, so that the career path of the employees should not windup in a blind lane.

$>$ The immediate superiors are the best judges to judge the needs of the employee's additional skills required for his future career growth.

$>$ 'Development gaps' and 'opportunity gaps' must be included in the performance-review operation of Career Development goals for each individual, as this will excel employee engagement and invariably impacts employee productivity.

\section{CONCLUSION}

It is couched that employees ${ }^{e e}$ job satisfaction is dependent on career development opportunities in their respective organizations in the banking sector. It can be generally concluded that banking sector in India is providing career development opportunities. Employees agreed they may leave their organization if they feel lack of career development activities. Private Banking sectors are practicing all career development activities as they want to increase employee's job satisfaction which ultimately leads to higher work efficiency and productivity. The study finds high efforts by management to attain satisfy and attract existed employees.

\section{REFERENCES}

[1] Shelton, S. (2001), the effects of employee development programs on job satisfaction and employee retention. International journal of business and public management vol.3(2), pp.10-60

[2] Pathak Neetu. (2008), "Corporate Training Program- An Effective Instrument for Organisational Development: A Comparative Study of Public and Private Sectors", The Indian Journal of Commerce, School of Management Studies, Vol.61, No.3, Maiden Garhi, New Delhi, pp 113-119.

[3] Anne Roe, (1956), "Human Resource Systems and Competitive Advantage: A Competency Based Perspective", Academy of Management Review, Vol.19, pp.699-727.

[4] Lawler, E.E., (1971), "Pay and Organizational Effectiveness: A Psychological View”, New York: McGraw-Hill.

[5] Pattanaik, (1990), "When Employees Feel Betrayed: A Model of How Psychological Contract Violation Develops", Academy of Management Review, Vol. 22, pp. 226-56. 
[6] Bansal, M.P., (1991), "Human Resources Development in Public Enterprises”, RBSA publications, Jaipur.

[7] Levinson, D.J., (1996), “A Connection of Adult Development", American Psychologist Journal, Vol.41, No.3, p-13.

[8] Brooks, J.L. and Sears, A., (2001), "Predictors of Organizational Commitment, Variations across Career Stages", Journal of Vocational Behaviour, Vol.38, pp.53-64.

[9] Mowday, R., Porter, L.W. and Steer, R.M., (1992), "Employee-Organization linkages, the Psychology of Commitment, Absenteeism and Turnover", San Diego, CA. Academic Press.

[10] Ornstein, S., Cron, W.L. and Slocum, J.W., (1999), "Life Stages Versus Career Stage, A Comparative Test of the Theories of Levinson and Super", Journal of Organizational Behaviour, Vol.10, pp.117-133.

[11] Greenhaus, J.H., Callanan, G.A. and Godshalk, V.M., (2000). "Career Management", (3rd ed.), Fort Worth, TX:Dryden Press.

[12] Morrow, P.C. and McElroy, J.C., (1997), "Work Commitment and Job Satisfaction over Three Career Stages", Journal of Organizational Behavior, Vol.30, pp.330-346.

[13] Cohen, A., (2001), "Career Stage as a Moderator of the Relationships between Organizational Commitment and its Outcomes: Ameta Analysis", Journal of Organizational Psychology, Vol.6, No.4, pp. 253-268.

[14] Meyer, J.P., Allen, N.J. and Smith, C.A., (2003), "Commitment to Organizations and Occupations; Extension and Test of a Three-Component Conceptualization”, Journal of Applied Psychology, Vol.78, pp.538-551.

[15] Winter, R., (2000), "Trouble at Mill: Quality of Academic Work Issues within a Comprehensive Australian University", Ph.D. Thesis, Department of Commerce and Business Administration, Shaurashtra University, Vol.18, pp.28-52.

[16] Kumar, B.P and Giri, V.N., (2009), "Effect of age and experience on job satisfaction and organizational commitment", The ICFAI Journal of Organizational Behaviour, Vol.8, No.2, pp.28-36.

[17] Kumar, B.P and Giri, V.N., (2009), "Effect of age and experience on job satisfaction and organizational commitment", The ICFAI Journal of Organizational Behaviour, Vol.8, No.2, pp.28-36.

[18] Ashwathappa, K., (2008), "Human Resource Management" Prentice Hall of India Pvt. Ltd.

[19] Kothari, C.R., (1988), "Research Methodology - Methods and Techniques", Wiley Eastren Ltd, New Delhi, p.180 and 340. 